\title{
IMAMAT DAN KENABIAN
}

\author{
Raidin Sinaga*
}

\begin{abstract}
Abstrak
Pada hakekatnya imamat tidak bisa dipisahkan dari kenabian. Hal ini sangat jelas untuk para bapak Konsili Vatikan II yang diungkapkan dalam Dekrit tentang Pelayanan dan Kehidupan Para Imam: " Tuhan Yesus, 'yang oleh Bapa dikuduskan dan diutus ke dunia' (Yoh 10: 36) mengikutsertakan seluruh Tubuh mistik-Nya dalam pengurapan Roh yang diterima-Nya sendiri" (PO, 2). Dengan kata lain, sudah sejak awal mula, dalam "benak Allah", kesatuan itu ada dan harus dijaga dan dipertahankan. Dalam perjalanan Sejarah Keselamatan hal ini tidak langsung jelas, dibutuhkan proses yang panjang untuk sampai pada pemahaman yang benar. Hal itu nampak dari pemahaman tentang peran dan makna nabi dan imam dalam Perjanjian Lama sampai dengan paham dan praktek Gereja sebelum dan sesudah Konsili Vatikan II.
\end{abstract}

Kata-kata kunci: imamat, kenabian, Allah, Yesus Kritus, bangsa Yahudi, para rasul, nabi, imam, raja.

\section{Pengantar}

Cara yang paling baik untuk memperoleh pemahaman yang tepat dan dasariah tentang hubungan imamat dan kenabian ialah dengan mempelajarinya dalam pengalaman bangsa Yahudi dan hidup Yesus Kristus. Menurut Konsili Vatikan II, "dari bangsa Yahudi", yang merupakan saudara tua orang Kristen, "lahirlah para rasul, dasar dan saka guru Gereja", dan dengan demikian Gereja "menerima santapannya dari akar zaitun yang baik". ${ }^{1}$ Di samping itu, kekristenan sebagai nama ${ }^{2}$ dan hakekat selalu dihubungkan dan mengacu pada apa

1 Kosili Vatikan II, "Perayaan Tentang Hubungan Gereja dengan Agama-agama bukan Kristiani" (NE), dalam Dokumen Konsili Vatikan II, diterjemahkan oleh R Hardawiryana (Jakarta: Dokumentasi dan Penerangan KWI-Obor, 1993), no.4.

2 Di Antiokialah pengikut-pengikut Kristus untuk pertama kalinya disebut Kristen (Kis Ras 11:26). 
yang dihidupi dan diajarkan oleh Sang Guru, yaitu Yesus Kristus yang adalah Imam Agung dan Nabi par excellence. ${ }^{3}$

Pendasaran historis-biblis dan kristologis akan sangat menolong untuk memperoleh paham yang tepat tentang nabi ${ }^{4}$ dan bagaimana Gereja mengajarkan hubungan imamat dan kenabian. Ajaran ini harus dijabarkan dan diaktualisir dalam hidup setiap orang yang karena baptisan "disucikan menjadi kediaman rohani dan imamat suci" 5 , dan bagi mereka yang berdasarkan sakramen imamat "ditahbiskan menurut citra Kristus, Imam Agung yang abadi (lih. Ibr 5:1-10; 7:24; 9:11-28), untuk mewartakan Injil serta menggembalakan umat beriman dan untuk merayakan ibadat ilahi, sebagai imam sejati Perjanjian Baru"6.

\section{Dasar Historis-Biblis dan Kristologis}

Kalau kita membaca Kitab Suci dengan cermat, maka akan tampak perbedaan paham imamat antara PL dan PB. Dalam umat Perjanjian Lama ada tiga peran penting: Imam, Nabi dan Raja. Ketiga peran tersebut dijalankan oleh orang yang berbeda-beda. Dalam umat Perjanjian Baru, peran Raja semakin "menjauh dari Bait Suci", sedangkan fungsi Imam dan Nabi menyatu dalam Yesus Kristus. Mulai muncul peran baru atas panggilan Yesus sendiri, yakni, para Rasul. Para Rasul inilah yang melanjutkan misi pewartaan dan pengudusan (Mt. 28:18-20).

\section{Sebelum Yesus Kristus: "Spesialisasi"}

Secara umum dapat dikatakan bahwa dalam praktek hidup keagamaan dan kemasyarakatan Yahudi, Imam, Nabi dan Raja dijabat oleh orang-orang yang berbeda. Di samping perbedaan orangnya,

${ }^{3}$ Kenan B. Osborne, Priesthood. A History of the Ordained Ministry in the Roman Catholic Church (New York/Mahwah: Paulist Press, 1988), hlm. 3.

${ }^{4}$ Dalam bukunya Prophecy and Religion in ancient China and Israel, yang terbit tahun 1956, H. H. Rowley mengatakan bahwa di Cina antic juga ada nabi seperti yang dikenal di Israel. Pandangan ini tentu mengabaikan kekhasan kenabian dalam PL (Lih. H. Kung, Ebraismo, diterjemahkan dari bahasa Jerman oleh Giovanni Moretto [Milano: Rizzoli, 1995], hlm. 105)

5 Konsili Vatikan II, "Konstitusi Dogmatis tentang Gereja" (LG), dalam Konsili Vatikan II, diterjemahkan oleh R. Hardawiryana (Jakarta: Dokumentasi dan Penerangan KWI - Obor, 1993), no. 10. Untuk selanjutnya dokumen ini akan dikutip dengan singkatan LG dan diikuti nomor.

${ }^{6} \mathrm{LG}$, no. 28. 


\section{Raidin Sinaga, Imamat dan Kenabian}

ketiganya juga melaksanakan tugas di tempat yang berbeda. Imam di dalam Bait Allah, Nabi di tengah masyarakat, Raja di dalam istana. Ketiganya mewakili Allah dalam mengajar, menguduskan dan memimpin umat Allah. Mereka harus bekerja sama dengan peran mereka yang khas untuk mewujudkan sebuah Kerajaan seperti yang dijanjikan dan dikehendaki Allah. Sayang bahwa kerja sama tersebut kadang atau sering mengalami gangguan karena ketidaksetiaan satu atau dua pihak. Yang lebih sering tidak setia ialah Raja dan Imam, dan yang paling setia adalah Nabi.

Seorang Nabi adalah "Juru Bicara Allah".7 Sebagai juru bicara dia harus tetap sadar bahwa segala sesuatu yang dia sampaikan, sehubungan dengan tugasnya sebagai Nabi, bukan dari diri dan kehendak sendiri melainkan dari Dia yang diwakilinya, yakni Allah. Oleh karena itu, dari seorang Nabi sangat dituntut hubungan pribadi yang erat dan mendalam dengan Allah. Dengan kata lain, "pengalaman rohani menjadi hakekat dari hidup seorang Nabi: hubungan personal dengan Tuhan, doa, devosi, ketaatan moral kepada kehendak ilahi". ${ }^{8}$ Otoritas dari kata-kata yang diucapkan oleh Nabi tergantung dari ketaatannya kepada kehendak Allah (bdk. 1 Sam 3:10; Yes 6:8; Yer 1:410). ${ }^{9}$ Ada kalanya Allah sendiri menjamin otoritas tersebut; misalnya dalam perutusan Nabi Yeremia "Allah mengulurkan tangan-Nya dan menjamah mulut"-nya. Artinya, Allah sendiri yang menaruh kata-kata ke dalam mulut Yeremia (Yer 1:9). ${ }^{10}$

Cara bagaimana seorang Nabi menyampaikan kehendak Allah banyak "tergantung dari situasi". Ada kalanya dia sebagai pembawa berita dan pewarta, penerjemah; ada kalanya dia harus menghibur dengan janji, meneguhkan, dan membangkitkan semangat dan harapan;

7 Untuk pemahaman tentang diri dan tugas nabi kami mengacu pada Serpulus Simamora, Kitab Nabi-Nabi Besar: Yesaya, Yeremia, Yehezkiel, Daniel (Sinaksak-Pematangsiantar: STFT St. Yohanes, 2004), hlm. 1-22; juga Collin Brown, "Prophet", dalam C. Brown (ed.), The New International Dictionary of New Testament Theology. Vol. 3 (Exenter, Devon, U.K.: The Paternoster Press, 1978), hlm. 74-89.

8 S. Simamora, Kitab Nabi-Nabi ..., hlm. 2.

75.

9 S. Simamora, Kitab Nabi-Nabi..., hlm. 3-4; C. Brown, "Prophet", hlm.

10 R.F. Bhanu Viktorahadi, "The Authenticity of the Word in the Expression 'Yahweh Touching Jeremiah's Mouth' (Jer 1:4-10)", dalam Melintas 25/2 (2009), hlm. 179-205. 
ada kalanya dia harus mengingatkan, menuduh dan mengancam. ${ }^{11}$ Sebagai "Juru Bicara Allah" para Nabi penulis pada abad VIII-VII Seb.M hanya taat kepada Allah saja. Dengan keras mereka mengkritik bangsa Israel setiap kali menjauh dari perjanjian. Salah satu kritik mereka ialah pemahaman tentang sejarah: bangsa Israel pelan-pelan bergerak dari sejarah keselamatan, di mana mereka sangat mengandalkan Allah, ke sejarah sekular di mana mereka semakin mengandalkan kekuatan sendiri sebagai bangsa. Para Nabi juga mengkritik praktek keagamaan dan hidup para Imam yang tidak lagi menampakkan "saluran keselamatan" tetapi lebih sebagai formalisme kultis dengan perayaanperayaan tanpa penghayatan. Para Nabi juga mengkritik ketidakadilan sosial yang dilakukan oleh kelompok-kelompok tertentu. Dengan tidak segan-segan para Nabi juga mengingatkan, menuduh dan mengancam para Raja yang tidak memerintah sesuai dengan kehendak Allah. ${ }^{12}$

Seperti Nabi, Raja juga dipilih oleh Allah (1 Sam 9:17; 1 Sam 16:1) dan diurapi oleh seorang Nabi (dan Imam). ${ }^{13}$ Karena rahmat Allah seseorang bisa menjadi Raja dan oleh karena itu dari seorang Raja dituntut kesetiaan kepada Allah yang memilihnya untuk memimpin bangsa Israel ${ }^{14}$ atau umat Allah. Jadi, ada hubungan yang erat antara tugas kenabian dengan pemimpin Israel. Raja yang dipilih Allah, diurapi dan dikoreksi oleh Nabi. Di atas kedua hal inilah terletak otoritas seorang Raja: pilihan dan pengakuan Allah yang bisa dilihat dari pengurapan dan pengakuan seorang Nabi kepadanya.

Berbeda dari Nabi dan Raja, Imam dan imamat untuk bangsa Israel awalnya bukanlah panggilan atau pilihan Allah melainkan suatu tugas dan jabatan. ${ }^{15}$ Umumnya seorang Imam ditunjuk oleh keluarga,

11 Bdk. S. Simamora, Kitab Nabi-Nabi ..., hlm. 3.

12 Bdk. H. Küng, Ebraismo ..., hlm. 109-111.

${ }^{13}$ Salomo diurapi oleh nabi Natan dan imam Zadok (1 Raj 1:34), Saul dan Daud diurapi oleh nabi Samuel (1 Sam 10:1; 1 Sam 16:12-13).

14 Roland de Vaux, Ancient Israel. Its Life and Institutions, diterjemahkan dari bahasa Prancis oleh John Mac Hugh (London: Darton, Longman and Todd, 1961), hlm. 100-102; bdk. John H. Heyes and J. Maxwell Miller (ed.), Israelite and Judean History (London-Philadelphia: SCM Press-Trinity Press International, 1977), hlm. 285-380; bdk. Juga H. Kung, Ebraismo..., hlm. 87-104.

${ }^{15}$ Dalam hal ini kami mengikuti paparan dari Roland de Vaux, Ancient Israel..., hlm. 346-357; juga J. Baehr, "Priest, High Priest", dalam Colin Brown, The New International Dictionary..., hlm. 32-42; bdk. Serpulus Tano Simamora, "Imam dan Imamat dalam Perspektif Biblis", dalam Persaudaraan 3/VII (JuliSeptember 2009), hlm. 29-38. 


\section{Raidin Sinaga, Imamat dan Kenabian}

suku atau Raja menjadi pelayan rohani di sebuah tempat suci (sanctuary). Jabatan Imam dan institusi imamat sendiri memang baru ada setelah bangsa Israel tidak lagi berpindah-pindah. Sebelumnya 'fungsi Imam' dijalankan oleh bapak keluarga atau orang yang ditunjuk untuk tugas tersebut. Tugas Imam awalnya adalah memberitahukan kehendak Allah (orakel) kepada mereka yang mencarinya, kemudian mengajar dan mempersembahkan kurban.

Satu hal mendasar yang membedakan Imam/imamat Perjanjian Lama dari imamat Perjanjian Baru dan imamat yang kita imani saat ini adalah tahbisan. Mereka tidak kudus dan suci karena tahbisan - sebab mereka tidak ditahbiskan - tetapi dikuduskan oleh dan untuk tugas yang mereka lakukan (1 Sam 7:1). Oleh sebab itu, mereka harus "dipisahkan dari dunia" untuk tugas suci dan luhur tersebut (bdk. Bil 10:8; 1 Taw 23:13). Pemisahan itu terutama jelas dari pelbagai larangan dan aturan yang harus mereka patuhi (Im 21:1-24), yang tidak menjadi larangan dan kewajiban bagi mereka yang bukan Imam.

Di samping "imamat jabatan" ini, PL juga berbicara tentang "imamat umum" atau lebih tepat disebut sebagai "kerajaan Imam" (Kel 19:6). Septuaginta menerjemahkannya dengan frase basileion hieratuma, imamat rajawi. Ada pelbagai pendapat tentang arti "kerajaan Imam" ini. Yang pertama: semua orang Israel bisa langsung berhubungan dengan Yahweh, dan bangsa Israel bertugas sebagai Imam bagi bangsa-bangsa lain. Kedua, bangsa Israel dipilih dari antara bangsa-bangsa menjadi "Imam Tuhan" (Yes 61:6). Dalam hal ini, yang penting bagi kita adalah dalam PL sendiri sudah ada cikal bakal pemahaman tentang imamat umum yang juga disebut dalam PB (1 Ptr 2:9; Why 1:6; 5:10; 20:6). ${ }^{16}$

\section{Yesus Kristus Puncak Kenabian dan Imamat}

Imamat dan kenabian dalam PL sangat penting terutama sebagai pemakluman awal akan Yesus Kristus yang adalah Nabi dan Imam eskatologis yang dijanjikan. Dalam Dia dipenuhi, dipersatukan dan berpuncak kenabian dan imamat PL. ${ }^{17}$ Kita sudah mengatakan bahwa Nabi, Imam dan Raja adalah "wakil Allah". Hal ini tidak berlaku "secara teknis" untuk perutusan dan tugas Yesus. Dia bukan wakil tetapi Allah sendiri. Nabi dan Imam dipilih dari antara manusia dan diangkat menjadi Nabi dan Imam. Yesus bukan berasal dari manusia tetapi

${ }^{16}$ J. Baehr, "Priest...", hlm. 36-37.

${ }^{17}$ Bdk. H. Küng, Ebraismo..., hlm. 113. 
diutus Bapa dan turun ke dunia untuk menjadi pengantara Allah bagi kita.

\section{Yesus Sebagai Imam}

Yesus sendiri tidak pernah menyebut diri Imam. Dalam PB juga tidak pernah Dia disebut Imam. Satu-satunya tempat di mana Dia disebut sebagai Imam adalah Surat Ibrani yang menyebut-Nya sebagai Imam Besar (Ibr 4:14-10:18). Disebut Imam Besar atau Imam Agung karena dua hal: a) masuk ke tempat mahakudus' ${ }^{18}$ yang hanya boleh dimasuki Imam Agung (Ibr 9:3.7); b) Mempersembahkan korban dengan penumpahan darah (Ibr 8:3). Dalam dua hal inilah terutama dilihat persamaan dan perbedaan antara Imam Agung suku Lewi dan Yesus Kristus sebagai Imam Agung Perjanjian Baru. ${ }^{19}$ Perbedaan yang akan kita lihat akan menunjukkan bahwa imamat Yesus Kristus jauh melampaui Imam Agung Perjanjian Lama atau Imam Agung suku Lewi. Yesus Kristus adalah Imam Agung sempurna dan abadi.

Sebelum melukiskan perbedaan dalam dua hal yang disebut di atas, surat Ibrani pertama-tama menunjukkan perbedaan hakekat dari keduanya. Berbeda dengan Imam Agung suku Lewi, Yesus adalah Imam "menurut peraturan Melkisedek" (Ibr 5:6.10) artinya "bukan karena garis keturunan Imami, melainkan karena pilihan Allah (Ibr 5:45.10); imamat-Nya kekal (Ibr 5:6; 6:20) tidak berawal dan tidak berkesudahan (Ibr 7:3)", 20 "yang menjadi Imam bukan berdasarkan peraturan-peraturan manusia, tetapi berdasarkan hidup yang tidak dapat binasa" (Ibr 7:16).

18 Tempat imam ("pengimaman") dalam Bait Allah terdiri atas dua bagian: 1) Tempat kudus yang bisa dimasuki semua imam-imam. Disebut juga kemah depan di mana disimpan kaki dian dan meja dengan roti sajian (Ibr 9:2.6)); 2) Tempat mahakudus yang hanya boleh dimasuki oleh Imam Besar, dan terletak di belakang kemah pertama dipisahkan oleh sebuah tirai. Di tempat mahakudus ini ada "mezbah pembakaran ukupan dari emas, dan tabut perjanjian, yang seluruhnya disalut dengan emas; di dalam tabut perjanjian itu tersimpan buli-buli emas berisi manna, tongkat Harun yang pernah bertunas dan loh-loh batu yang bertuliskan perjanjian, dan di atasnya kedua kerub kemuliaan yang menaungi tutup pendamaian" (Ibr 9:3-5)

${ }_{19}$ Di sini kami mengikuti pemikiran dari Martin Harun, "Perjanjian Baru dan Imamat Katolik", dalam Imam Jantung Hati Yesus. Kumpulan Refleksi dari Berbagai Sudut Pandang tentang Imamat dan Pelayanan Imam (Jakarta: Obor, 2009), hlm. 155-177.

${ }^{20}$ Serpulus Tano Simamora, "Imam..., hlm. 36. 


\section{Raidin Sinaga, Imamat dan Kenabian}

a. Masuk ke tempat mahakudus: Pada Hari Raya Pendamaian (Yom Kipur) Imam Agung dua kali masuk ke tempat mahakudus "untuk mencurahkan darah hewan korban pada tutup peti perjanjian sebagai wakil semua bangsa untuk penghapusan dosa pribadinya dan kemudian untuk dosa-dosa umat". Yesus Kristus, Imam Agung kita masuk bukan ke dalam ruang mahakudus buatan tangan manusia, tetapi "mendapat akses penuh pada Allah, mendapat kedudukan di sebelah kanan Allah di surga". ${ }^{21}$ Hal ini cukup jelas dilukiskan surat Ibrani dengan kata-kata, Kristus "telah melintasi kemah yang lebih besar dan yang lebih sempurna, yang bukan dibuat oleh tangan manusia" (Ibr 9:11). Yesus sendiri tidak perlu masuk dua kali ke tempat mahakudus karena Ia tidak berdosa.

b. Mempersembahkan korban dengan penumpahan darah: Imam Agung masuk ke tempat mahakudus untuk mempersembahkan hewan. Dan ini diulangi setiap tahun demi penghapusan dosa Imam dan bangsa Israel. Darah yang dicurahkan Yesus adalah darah-Nya sendiri, bukan darah hewan. Hal itu dilakukan-Nya sekali untuk selama-lamanya. Dengan pengorbanan-Nya di atas salib Dia telah mempersembahkan "persembahan yang tak bercacat" (Ibr 9:14) atau persembahan yang sempurna (bdk. Ibr 10). Dengan persembahan sempurna ini, Yesus telah mendamaikan seluruh dunia dan manusia dengan Allah, sekali untuk selama-lamanya. Dengan persembahan ini Yesus juga telah membuka tirai sehingga manusia bisa berjumpa dengan Allah untuk memasuki tempat mahakudus. Hal ini berbeda dengan apa yang terjadi pada Hari Raya Pendamaian: hanya Imam Agung yang boleh masuk, sementara umat Israel tetap tinggal di luar. ${ }^{22}$

\section{Yesus Sebagai Raja - Gembala}

Apakah Yesus seorang Raja? Di hadapan Pilatus Yesus menyatakan bahwa Dia adalah Raja. Namun kerajaan-Nya bukan dari dunia ini. Kerajaan Yesus adalah kerajaan rohani, oleh karena itu Dia adalah Raja rohani. Kerajaan-Nya tidak didasarkan atas kekerasan melainkan atas kerajaan dalam hati manusia. Dia datang untuk menaklukkan dunia dari kerajaan setan, untuk membebaskan manusia

${ }^{21}$ Martin Harun, "Perjanjian...", hlm. 157.

22 Bdk. Martin Harun, "Perjanjian...", hlm. 57; Serpulus Tano Simamora, "Imam...", hlm. 35-36. 
dari perbudakan dosa. Senjata yang digunakan adalah senjata kasih. Di samping itu Raja rohani ini datang untuk menyatakan kebenaran, yakni kebenaran tentang Allah, kebenaran mengenai manusia sendiri dan kebenaran tentang hidup..$^{23}$

Gambaran yang lebih popular tentang Yesus bukanlah sebagai Raja melainkan sebagai Gembala. Yesus adalah Gembala yang baik (Pastor bonus). Ciri-ciri seorang Gembala yang baik ialah bersedia memberikan nyawanya bagi domba-dombanya, mengenal dombadomba dan domba-domba mengenalnya (Yoh 10:11.14), mencari domba yang hilang (Mt 18:12-14; Lk 15:3-7). Sehubungan dengan gambaran ini, perlu kita ingat keinginan Yesus tentang penerus tugas dan misi-Nya yang Dia ungkapkan di pantai danau Tiberias sesudah Dia bangkit. Tiga kali Yesus bertanya kepada Petrus tentang cintanya kepada Yesus, dan tiga kali juga Yesus mengatakan "Gembalakanlah domba-domba-Ku" sesudah Petrus memberitahukan kedalaman cintanya kepada Tuhan (Yoh 21:15-17).

Para pemimpin Gereja diinginkan menjadi gembala, dan dasar kegembalaan mereka adalah cinta dan kerendahan hati. "Kamu tahu, bahwa pemerintah-pemerintah bangsa-bangsa memerintah rakyatnya dengan tangan besi dan pembesar-pembesar menjalankan kuasanya dengan keras atas mereka. Tidaklah demikian di antara kamu. Barang siapa ingin menjadi besar di antara kamu, hendaklah ia menjadi hambamu; sama seperti Anak Manusia datang bukan untuk dilayani, melainkan untuk melayani dan untuk memberikan nyawa-Nya menjadi tebusan bagi banyak orang" (Mat 20:25-28).

\section{Yesus Sebagai Nabi}

Hanya di beberapa tempat dalam PB Yesus disebut Nabi, dan itupun umumnya oleh masyarakat (Mrk 6:15 par Lk 9:8; Mat 16:14 par Mrk 8:28; Lk 7:16; 9:19; Yoh 6:14). Secara langsung Yesus tidak pernah menyebut diri-Nya seorang Nabi. Dalam beberapa kesempatan secara tidak langsung Dia "mengaku" sebagai Nabi: “...Aku harus meneruskan perjalanan-Ku, sebab tidaklah mestinya seorang Nabi dibunuh kalau tidak di Yerusalem" (Lk 13:33); ketika ditolak di Nazaret Dia berkata

${ }^{23}$ William Barclay, Injil Yohanes Pasal 8-21. Seri Pemahaman Alkitab Setiap Hari, diterjemahkan oleh S.H. Widyapranawa (Jakarta: BPK Gunung Mulia, 2003), hlm. 380-381. 


\section{Raidin Sinaga, Imamat dan Kenabian}

"Seorang Nabi dihormati di mana-mana, kecuali di tempat asalnya sendiri dan di rumahnya" (Mat 13:57). ${ }^{24}$

Dari cerita dan pelukisan tentang Yesus dalam PB tidak dapat diragukan kebenaran iman tentang diri-Nya sebagai Nabi yang paling besar. Dalam Dia berpuncak panggilan dan tugas kenabian. Yesus tidak hanya menerima dan meneruskan Sabda Allah, tetapi Dia sendirilah Sabda Allah (bdk. Yoh 1:1-18). "Ia tidak hanya mewartakan keselamatan, tetapi Dialah keselamatan semua orang. Ia tidak hanya mewahyukan tentang Allah, tetapi Ia sendiri adalah Wahyu Ilahi" ${ }^{25}$ Sebagai seorang Nabi Yesus mengajar bangsa Israel tentang Allah, tentang Kerajaan Allah, tentang cinta dan pengampunan, dan tentang kebenaran-kebenaran Iman yang lain. Dia juga mengungkapkan tentang kebenaran-kebenaran yang baru untuk melengkapi kebenarankebenaran yang lama. Dia menghibur, memberi harapan, menyembuhkan, dan menghidupkan. Dia tidak segan-segan menegor, mengancam dan malah mengutuk. Dan karena semua ini Ia akhirnya mengalami salib para Nabi juga, yakni dibunuh di Yerusalem (Lk 13:33).

Sebagai kesimpulan dari bagian ini dapat dikatakan bahwa dalam PL ada tiga peran dan tokoh utama yang diutus Allah demi keselamatan Umat-Nya. Mereka itu adalah Nabi, Imam dan Raja. Ketiganya mempunyai tugas berbeda-beda tetapi saling melengkapi. Nabi sebagai pewarta, Imam sebagai 'pengudus', dan Raja sebagai pemimpin. Dalam Yesus semua peran itu bersatu dan memuncak serta disempurnakan. Dialah Utusan Allah yang utama, dan yang sudah dinanti-nantikan oleh semua orang. Dia akan menjadi model untuk semua perutusan sesudahnya.

\section{Imamat dan Kenabian Dalam Gereja}

Sesudah periode Yesus, Utusan dan Juru Bicara Allah dilaksanakan oleh para Rasul. Sesudah periode para Rasul, mulai periode para Imam atau hirarki (Uskup-Imam-Diakon). ${ }^{26}$ Sejak saat ini hirarki-lah yang menjadi "Juru Bicara Allah". Hirarki-lah satu-satunya

24 Bdk. C. Brown, "Prophet", hlm. 83.

25 A. Heuken, "Nabi", dalam Ensiklopedi Gereja. Vol 6 (Jakarta: Cipta Loka Caraka, 2005), hlm. 9.

26 Sampai abad kedua masih berlanjut peran nabi-nabi dalam Gereja, tetapi sesudahnya seolah-olah total menghilang (Kenan B. Osborne, Priesthood..., hlm. 127-128). 
yang menjadi saluran resmi kehendak Allah. Imamat menjadi sangat penting dan menjadi kriteria pembagian seluruh umat Allah: imamat umum dan imamat jabatan atau pelayanan.

\section{Peran Imam Sangat Menonjol}

Yesus Kristus yang adalah Nabi, Imam dan Gembala, memilih para Rasul dan murid untuk melanjutkan misi penyelamatan. Isi dari misi dan bagaimana misi itu harus dilaksanakan cukup jelas, “...pergilah, jadikanlah semua bangsa murid-Ku dan baptislah mereka dalam nama Bapa dan Anak dan Roh Kudus, dan ajarlah mereka melakukan segala sesuatu yang telah Ku-perintahkan kepadamu" (Mat 28:19-20). Untuk mewujudkan misi tersebut penting pewartaan (kerygma) dan sakramen. Di tempat lain, Yesus sendiri mengatakan kepada Petrus sebelum Dia kembali ke surga, "Gembalakanlah dombadomba-Ku" (Yoh 21:15.16.17). Dengan kata lain, sangat jelas dalam Kitab Suci bahwa di dalam Gereja yang dikehendaki oleh Yesus Kristus harus ada pewarta (Nabi), pelayan sakramen (Imam), dan pemimpin yang melayani dan memberikan diri untuk kawanan (Gembala).

Dalam perjalanan sejarah Gereja Katolik, karena pengaruh dunia, kesetiaan pada perutusan tersebut tidak selalu terjamin. Malah, sangat lama Gereja Katolik hanya diurus oleh Imam atau hirarki. Peran Nabi dan Gembala "hilang ditelan" oleh Imam. Gereja Katolik menjadi sangat imami, sangat hirarkis dan sibuk dengan urusan-urusan "Bait Suci" dan menjauh dari dunia (fuga mundi). Gereja mungkin masih signifikan ke dalam tetapi tidak relevan ke luar dirinya. Hal ini disebabkan oleh paham teologis yang dianut atau mempengaruhi pemikiran Gereja.

Pertama, Imam dihubungkan bukan dengan komunitas tetapi dengan Ekaristi. Pandangan ini sudah mulai sebelum Konsili Trente (1545 - 1563), dan mencapai puncaknya pada Konsili Trente sendiri. Pada masa itu, kata Yohanes Duns Scotus, tindakan yang paling luhur dalam Gereja adalah Konsekrasi Ekaristi yang sebenarnya sangat sederhana. Hanya Imam atau yang ditahbiskan Imam bisa melakukan karena melalui tahbisan itu Imam mendapat kuasa dari Kristus. Cukup kuat keyakinan saat itu bahwa Imam ditahbiskan pertama-tama untuk perayaan Ekaristi. Oleh karena itu Imam dianggap sebagai "the agent for transubstantiation", orang yang pekerjaannya ialah mengubah roti dan anggur menjadi Tubuh dan Darah Kristus. Konsili Trente sendiri mengafirmasikan dan meneguhkan pandangan itu dalam Dekrit tentang 


\section{Raidin Sinaga, Imamat dan Kenabian}

Sakramen Imamat, "Sacrificium et sacerdotium ita Dei ordinatione coniuncta sunt", menurut hukum ilahi kurban Ekaristi dan Imam berhubungan satu dengan yang lain. ${ }^{27}$ Aplikasi yang kurang atau tidak tepat pada hidup dan penghayatan para tertahbis ialah menjadi penguasa bukan gembala, mengutamakan hukum dan aturan di atas cinta.

\section{Struktur Tiga Serangkai: Nabi-Imam-Raja (Gembala) Sebagai Sebuah Konstruksi Teologis}

Kita sudah melihat bahwa Yesus, entah secara langsung atau tidak, disebut sebagai Nabi, Imam dan Raja (Gembala), tetapi tidak di satu tempatpun dalam PB ketiga gelar atau fungsi itu sekaligus dikenakan pada-Nya. Umumnya disebut secara terpisah tanpa menyinggung yang lain, dan tidak pernah juga dikatakan bahwa ketiga fungsi ini menjadi rangkuman dari seluruh misi penyelamatan dari Yesus Kristus. ${ }^{28}$ Oleh karena itu dapat disimpulkan bahwa rumusan tiga serangkai, bersama dan tak terpisahkan Nabi-Imam-Raja sebagai misi Yesus bukanlah sesuatu yang menyangkut wahyu ilahi tetapi hanyalah sebuah konstruksi teologis.

\section{Penemuan Kalvin}

Bapak-bapak Gereja kadang menggunakan tiga fungsi atau gelar itu tetapi tidak pernah bersama-sama. Paling-paling dua fungsi atau gelar digunakan bersama; dan yang paling sering adalah pasangan Imam dan Raja. Lalu, siapakah orang pertama yang menemukan atau menggunakan rumusan Nabi-Imam-Raja ini? Para ahli agak sepakat mengatakan bahwa John Kalvin-lah yang pertama menggunakan secara bersama ketiga fungsi dan tugas itu pada Yesus. Hal itu terjadi pada tahun 1536 dalam bukunya Institutio Christianae religionis. Susunan yang dia gunakan ialah Nabi-Raja-Imam. Yesus adalah Nabi yang paling utama karena Dia telah membawa ajaran sempurna; Yesus adalah Raja, lebih dalam arti rohani, yang merajai dan menaklukkan segala sesuatu,

27 DS 1764; Patrick J. Dunn, Priesthood. A Re-examination of the Roman Catholic Theology of the Presbyterate (New York: Alba Hause, 1990), hlm. 84-85; Daniel Donovan, What are They Saying about the Ministerial Priesthood? (New York/Mahwah: Paulist Press, 1992), hlm. 43.

${ }^{28}$ Pembahasan tentang topik ini dapat dilihat dalam Kenan B. Osborne, Priesthood..., hlm. 310-313. 
termasuk kematian dan setan; Dia adalah Imam yang mengampuni dan menjadi pengantara.

\section{Perbedaan Teologi Dalam Urutan}

Jelaslah bahwa susunan tiga serangkai tersebut tidak termasuk bagian dari tradisi teologi skolastik, yang sangat menentukan dan sampai sekarang sangat berpengaruh dalam teologi imamat Gereja Katolik, karena penemuan Kalvin terjadi lama sesudah puncak skolastik. ${ }^{29}$ Maka, bisa juga disimpulkan bahwa susunan tiga serangkai bukanlah bagian dari hakekat teologi imamat sejak awal. Bingkai pemikiran tentang imamat dalam susunan tiga serangkai Nabi-ImamRaja, datang kemudian.

Karena susunan tiga serangkai Nabi-Raja-Imam adalah penemuan Kalvin, maka awalnya tidak diterima dalam Gereja. Umumnya, hampir semua teolog Katolik berusaha menghindari pemakaian susunan tiga serangkai itu dalam pembicaraan tentang imamat. Namun, pada akhir abad XVIII dan awal abad XIX penemuan Kalvin itu pelan-pelan diterima dalam teologi dan KHK Gereja Katolik. Dan sejak abad XX sudah menjadi biasa dan menjadi skema utama dalam pembicaraan tentang teologi imamat: Yesus Kristus adalah NabiImam-Raja (Gembala), si tertahbis juga adalah Nabi-Imam-Raja (Gembala). ${ }^{30}$

Dalam pembicaraan tentang susunan tiga serangkai Nabi-ImamRaja, perlu diperhatikan urutannya. Seperti sudah kita sebut di atas, Kalvin menyusunnya sebagai berikut: Nabi-Raja-Imam. ${ }^{31}$ Urutan itu mau menekankan yang mana yang terutama dalam ajaran, penghayatan dan pelayanan. Umumnya Protestan mengikuti urutan ini karena mereka sangat menekankan peran utama dari sabda dan pewartaan. Dalam Gereja katolik ada pergeseran urutan dari Imam-Nabi-Raja ke

${ }^{29}$ Abad ke-13 adalah puncak atau jaman keemasan teologi skolastik, yang ditandai dengan pemikiran-pemikiran dari Thomas Aquino (Bdk. Giuseppe Occhipinti [ed.], Storia della Teologia 2: da Pietro Abelardo a Roberto Bellarmino [Bologna: Dehoniane, 1996], hlm. 137-187).

${ }^{30}$ Kenan B. Osborne, Priesthood..., hlm. 312.

31 Dalam penemuannya Kalvin mengaplikasikan susunan tiga serangkai nabi-raja-imam pada Yesus Kristus, tetapi tidak jelas apakah dia juga berbicara tentang skema tiga serangkai dalam hubungan dengan pelayan gerejawi dan umat beriman. 
Nabi-Imam-Raja (Gembala). Urutan yang pertama dipengaruhi oleh teologi imamat Trente, seperti sudah diterangkan di atas, di mana ada kuasa dan imam-sentris. Urutan kedua, melihat Imam bukan lagi dalam hubungan dengan Ekaristi, seperti yang pertama, tetapi dengan komunitas umat beriman. Nabi sebagai pewarta dan juru bicara menempati posisi yang pertama. Hal ini menjadi sangat jelas dalam urutan tugas perutusan para pelayan tertahbis: kewajiban yang pertama adalah "mewartakan Injil Allah kepada semua orang", karena dengan mendengar sabda-lah seseorang dapat beriman dan diselamatkan. ${ }^{32}$ Tugas pewartaan ini harus menjadi tugas awal, dan karena alasan itu isi tugas perutusan para Rasul dan murid Sang Guru adalah, "Pergilah ke seluruh dunia, wartakanlah Injil kepada segala makhluk" (Mrk 16:15).

\section{Konsili Vatikan II: Kembali ke Semangat Awal}

Dalam pidato pembukaan Konsili Vatikan II (11 Oktober 1962), Paus Yohanes XXIII dengan jelas menegaskan tujuan Konsili tersebut: pembaharuan (aggiornamento - up dating) Gereja Katolik Roma, dan promosi kesatuan umat Kristen. ${ }^{33}$ Konsili Vatikan sendiri merumuskan tujuan pastoral yang mau dicapai: "Pembaharuan Gereja, pewartaan Injil di seluruh dunia, dan dialog dengan dunia modern" 34 . Pembaharuan ini merupakan perwujudan dari kesetiaan kepada pendiri, kesetiaan kepada panggilan dan perutusannya, ${ }^{35}$ dan keinginan untuk kembali ke semangat awal. ${ }^{36}$

Ungkapan "pewartaan Injil di seluruh dunia, dan dialog dengan dunia modern" sepertinya mau mengatakan bahwa hal itu sebelumnya kurang atau tidak terlaksana. Hal itu bisa dimengerti sebab tugas kaum

32 Konsili Vatikan II, "Dekrit tentang Pelayanan dan Kehidupan Para Imam" (PO), dalam Dokumen Konsili Vatikan II, diterjemahkan oleh R. Hardawiryana (Jakarta: Dokumentasi dan Penerangan KWI- Obor, 1993), no. 4. Untuk selanjutnya dokumen ini akan dikutip dengan singkatan PO dan diikuti nomor.

${ }^{33}$ Lih. Enchiridion Vaticanum Vol I (EV/1), no. 45-50.59-61; Lih. Juga Richard R. Sinaga, Communion of Communities: Cara Baru Hidup Menggereja di Asia (Pematangsiantar: Panitia Sinode, 2008), hlm. 4-5.

34 PO, no. 12.

35 Bdk. Konsili Vatikan II, "Dekrit tentang Ekumenisme" (UR), dalam Dokumen Konsili Vatikan II, diterjemahkan oleh R. Hardawiryana (Jakarta: Dokumentasi dan Penerangan KWI- Obor, 1993), no. 6.

${ }^{36}$ Bdk. Tom Jacobs, Gereja Menurut Vatikan II (Yogyakarta: Kanisius, 1987), hlm. 11-12. 
tertahbis, karena kelekatan dengan Ekaristi, akhirnya hanya merayakan Ekaristi. Dengan kata lain, mereka "tinggal dalam bait suci", signifikan di dalam tetapi irrelevant ke luar. Dengan Konsili, Paus menginginkan Gereja yang hidup dan berkarya sesuai dengan maksud Pendiri. Untuk itu perlu kembali ke sumber dan berdialog dengan dunia. Hal itu tentu berlaku juga untuk kehidupan dan pelayanan Iimam. Konsili menghendaki para pelayan tertahbis relevan di dunia, maka mereka perlu "ke luar dari Bait Allah".

\section{Imamat Umum dan Imamat Pelayanan}

Dengan mengutip Perjanjian Baru, Konsili pertama-tama mengingatkan bahwa semua orang beriman adalah Imam dalam Yesus Kristus. ${ }^{37}$ Dalam LG no. 10 dikatakan bahwa melalui pembaptisan, karena pengurapan Roh Kudus anggota-anggota umat Allah "disucikan menjadi kediaman rohani dan imamat suci", menjadi "kerajaan dan Imam-Imam bagi Allah" (Why 1:6; 5:9-10). ${ }^{38}$ Sebagai Imam mereka harus mempersembahkan korban rohani. Imamat ini terlaksana "dalam menyambut sakramen-sakramen, dalam berdoa dan bersyukur, dengan memberi kesaksian hidup suci, dengan pengingkaran diri serta cinta kasih yang aktif" ${ }^{39}$

Dalam LG dikatakan bahwa imamat umum "berbeda hakekatnya dan bukan hanya tingkatnya" dari imamat jabatan dan pelayanan. ${ }^{40}$ Diterangkan bahwa walaupun imamat pelayanan didasarkan pada imamat umum, namun imamat jabatan atau pelayanan tidak bisa dimengerti melulu hanya sebagai intensifikasi dan peningkatan martabat dan misi imamat umum. Imamat jabatan atau pelayanan merupakan representasi dari tipe baru martabat dan kuasa imami. Dari kodratnya keduanya terarah satu dengan yang lain, karena partisipasi dalam imamat Kristus. Namun cara mereka berpartisipasi cukup berbeda. Imamat jabatan atau pelayanan berfungsi di dalam komunitas umat Allah keseluruhan. Dia ambil bagian dalam fungsi pengantara, yang terdiri dari dua aspek: "menaik" (ascending) dan

${ }^{37} \mathrm{PO}, 2$.

${ }^{38}$ Di tempat lain dikatakan, “... kamulah bangsa yang terpilih, imamat yang rajani, bangsa yang kudus, umat kepunyaan Allah sendiri..." (1 Ptr 2:9).

${ }^{39} \mathrm{LG}, 10$.

${ }^{40} \mathrm{LG}, 10$. 


\section{Raidin Sinaga, Imamat dan Kenabian}

"menurun" (descending). Dia juga berfungsi mengumpulkan, mempersatukan dan membangun umat Allah. ${ }^{41}$

\section{Imamat dan Kenabian}

Hubungan imamat dan perutusan (kenabian) Yesus Kristus dilukiskan oleh Konsili Vatikan II dengan kutipan dari Injil Yohanes, "yang oleh Bapa dikuduskan dan diutus" (Yoh 10:36). Kata "dikuduskan" berhubungan dengan imamat, sedangkan kata "diutus" menunjuk pada "kenabian". Di sinilah awal dan model dari petahbisan dan misi/perutusan Imam atau pelayan tertahbis dalam Gereja Katolik. ${ }^{42}$ Sudah sejak awal perutusan fungsi keimaman menyatu dengan fungsi kenabian, yakni pada misi Allah untuk menyelamatkan umat manusia dan dunia. Maka setiap imamat yang berasal dari Allah dan Yesus Kristus selalu terarah pada perutusan dan kenabian. Dengan kata-kata di atas, Penginjil Yohanes berhasil melukiskan dan merangkumkan seluruh aktivitas penyelamatan yang imami dan profetis dari Yesus Kristus, ${ }^{43}$ yang menjadi model dan norma untuk semua pelayanan dalam Gereja.

Sebagai Imam, semua orang beriman diharapkan bertekun dalam doa dan mempersembahkan diri sebagai korban yang hidup, suci, dan berkenan kepada Allah (Rm 12:1); sebagai Nabi, mereka harus memberi kesaksian tentang Kristus dan memberi pertanggungjawaban tentang hidup kekal. Para pelayan tertahbis, atas kuasa kudus yang ada pada mereka, wajib "menyelenggarakan korban Ekaristi atas nama Kristus, dan mempersembahkannya kepada Allah atas nama segenap umat". ${ }^{44}$ Para pelayan tertahbis wajib mewartakan cinta Allah, mengajar umat beriman dan memberi kesaksian tentang Kerajaan Allah dalam hidup mereka. ${ }^{45}$ Jadi kedua fungsi ini tidak terpisahkan dalam diri semua umat beriman, baik awam, biarawan-biarawati, maupun klerus.

${ }^{41}$ Aloys Grillmeier, "The People of God", dalam Herbert Vorgrimler (ed.), Commentary on the Documents of Vatican II, Vol I (London - New York: Burns and Oates - Herder and Herder, 1968), hlm. 158.

42 PO, 2; Friedrich Wulf, "Commentary on the Decree on the Ministry and life of Priest", dalam Herbert Vorgrimler (ed.), Commentary on the Documents of Vatican II, Vol. IV (London - New York: Burns and Oates - Herder and Herder, 1967) hlm. 218.

${ }^{43}$ Bdk. Friedrich Wulf, "Commentary...", hlm. 219.

${ }^{44} \mathrm{LG}, 10$.

${ }^{45} \mathrm{LG}, 28$. 
Kedua fungsi ini hanya menjadi efektif bila para pelayan "selalu berusaha menuju kekudusan yang semakin luhur"46, selalu berkomunikasi dengan Dia yang mengutus mereka. Para pelayan juga tidak hanya pintar berkata-kata tetapi juga harus siap berkorban (martyria). Dengan demikian perkataan mereka tidak kosong karena diwujudnyatakan dalam hidup dan perbuatan (deed-words). ${ }^{47}$

\section{Sebuah Rangkuman dan Refleksi}

Peristiwa yang terjadi di Nazaret, seperti dipaparkan penginjil Lukas, barangkali bisa membantu untuk refleksi akhir tulisan ini. Pada suatu hari sabat, menurut kebiasaan-Nya, Yesus masuk ke rumah ibadat. Kepada-Nya diberikan gulungan Kitab Nabi Yesaya. Ia menemukan dan membaca teks berikut: "Roh Tuhan ada pada-Ku, oleh sebab Ia telah mengurapi Aku, untuk menyampaikan kabar baik kepada orang-orang miskin; dan Ia telah mengutus Aku untuk memberitakan pembebasan kepada orang-orang tawanan, dan penglihatan bagi orangorang buta, untuk membebaskan orang-orang yang tertindas, untuk memberitakan tahun rahmat Tuhan telah datang" (Yes 61:1-2). Kemudian Ia mengajar mereka, kata-Nya: "Pada hari ini genaplah nas ini sewaktu kamu mendengarnya." Dan semua yang mendengarnya membenarkan Dia (bdk. Lk 4:16-22). Bisa dikatakan bahwa peristiwa ini merangkumkan dengan baik tugas perutusan Yesus sebagai Imam dan Nabi.

Kebiasaan masuk ke rumah ibadat: Dalam PL jelas bahwa seorang Imam adalah orang Bait Allah. Pekerjaannya dilaksanakan dalam Bait Allah. Penyelewengan dan kesalahannya dalam praktek ibadat akan dikritik oleh Nabi. Kewibawaan Imam terletak justru pada hakekatnya sebagai “orang Bait Allah". Nabi sendiripun, sebagai Juru Bicara Allah, pergi ke Bait Allah untuk mendengar Allah. Dengan demikian kebenaran pewartaannya akan terjamin. Semua orang beriman adalah Imam dan Nabi yang harus selalu bertanya diri: apakah saya tetap berkunjung ke Bait Allah dan berbicara dengan Dia yang mengurapi dan mengutus aku? Bila tidak, maka kewibawaan dan kuasanya sebenarnya lemah. Imam-Imam masa kini harus sekaligus "orang Bait Allah" dan "orang dunia" yang sanggup menyeimbangkan keduanya tanpa jatuh pada salah satu ekstrim. "Mereka tidak akan mampu menjadi pelayan Kristus, seandainya mereka tidak menjadi saksi dan

\footnotetext{
$46 \mathrm{PO}, 12$.

${ }^{47}$ Bdk. Friedrich Wulf, “Commentary...”, hlm. 219.
} 


\section{Raidin Sinaga, Imamat dan Kenabian}

pembagi kehidupan lain dari pada hidup di dunia ini. Tetapi mereka juga tidak akan mampu melayani sesama, seandainya mereka tetap asing terhadap kehidupan serta situasi sesama". ${ }^{48}$

Membaca Kitab Suci dan Mendengar: seorang Juru Bicara harus selalu bertanya dan menghubungi yang mengutus atau yang diwakilinya. Kalau tidak, maka ada bahaya bahwa ia akan menyampaikan bukan kata-kata dan maksud Pengutusnya, tetapi katakata dan maksudnya sendiri. Inilah Juru Bicara yang menyeleweng dari tujuan perutusan. Di samping itu, dia juga tidak boleh hanya menyimpan apa yang dia terima untuk dirinya sendiri, tetapi harus menyampaikan, membagikan atau mengajarkannya kepada orang lain.

Sabda Terwujud dalam Diri dan Hidup (deed-word): Seorang utusan harus orang pertama yang percaya akan apa yang mau disampaikan dan mencoba menghayati kata-kata dalam hidup harian. Hal ini akan sangat membantu untuk pewartaannya: "Hai tabib, sembuhkanlah dirimu sendiri" (Lk 4:23).

\section{Penutup}

Pengungkapan "Kebohongan Publik Pemerintah Indonesia" yang disampaikan oleh beberapa tokoh lintas agama merupakan seruan moral dan kenabian. Mereka keluar dari Bait Allah dan berusaha menjadi "the voice of the voiceless". Atau, dengan menggunakan ungkapan dari direktur Eksekutif Maarif Institute, Fajar Riza UI Haq: "Waktunya turun gunung karena komunikasi kayaknya sudah macet" ${ }^{49}$ Inilah contoh gerakan kenabian konkrit yang sungguh diharapkan akan menjadi pemicu dan benih untuk munculnya nabi-nabi lain atau kelompok nabi-nabi lain yang mengkritik pelbagai kebobrokan di dalam negeri ini.

Gerakan kenabian lintas agama ini tentu mengandaikan bahwa kita sendiri sudah dan harus membenahi rumah kita sendiri. Kalau tidak, kewibawaan gerakan ini akan kurang. Kita semua yang sudah diurapi menjadi Imam dan Nabi. Maka marilah juga keluar dari "Bait Allah" untuk mewartakan pembebasan bagi yang tertindas, untuk

$48 \mathrm{PO}, 3$.

${ }^{49}$ Ignasius Yophiandi Kurniawan, "Turun Gunung Membangun Istana. Sembilan Tokoh Agama Menyerukan Gerakan Moral. Dituding Berpolitik Praktis", dalam Tempo (24-30 Januari 2011), hlm. 35. 
menyampaikan seruan-seruan dan kritik-kritik profetis kepada mereka yang "berjalan di dalam kegelapan" dan menghantar mereka kepada terang dan kebenaran.

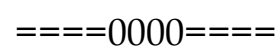

\section{DAFTAR PUSTAKA}

Barclay, William, Injil Yohanes Pasal 8-21. Seri Pemahaman Alkitab Setiap Hari, diterjemahkan oleh S.H. Widyapranawa, Jakarta: BPK Gunung Mulia, 2003.

Brown, Collin, "Prophet", dalam C. Brown (ed.), The New International Dictionary of New Testament Theology. Vol. 3, Exenter, Devon, U.K.: The Paternoster Press, 1978.

De Vaux, Roland, Ancient Israel. Its Life and Institutions, diterjemahkan dari bahasa Prancis oleh John Mac Hugh, London: Darton, Longman and Todd, 1961.

Dokumen Konsili Vatikan II, diterjemahkan oleh R Hardawiryana Jakarta: Dokumentasi dan Penerangan KWI-Obor, 1993.

Donovan, Daniel, What are They Saying about the Ministerial Priesthood? New York/Mahwah: Paulist Press, 1992.

Dunn, Patrick, J., Priesthood. A Re-examination of the Roman Catholic Theology of the Presbyterate, New York: Alba Hause, 1990.

Grillmeier, Aloys, "The People of God”, dalam Herbert Vorgrimler (ed.), Commentary on the Documents of Vatican II, Vol I, London - New York: Burns and Oates - Herder and Herder, 1968, hlm. 153-185.

Heuken, A., "Nabi", dalam Ensiklopedi Gereja. Vol 6, Jakarta: Cipta Loka Caraka, 2005. 


\section{Raidin Sinaga, Imamat dan Kenabian}

Heyes John, H and J. Maxwell Miller (ed.), Israelite and Judean History, London-Philadelphia: SCM Press-Trinity Press International, 1977.

Jacobs, Tom, Gereja Menurut Vatikan II, Yogyakarta: Kanisius, 1987.

Imam Jantung Hati Yesus. Kumpulan Refleksi dari Berbagai Sudut Pandang tentang Imamat dan Pelayanan Imam Jakarta: Obor, 2009.

Kung, H., Ebraismo, diterjemahkan dari bahasa Jerman oleh Giovanni Moretto, Milano: Rizzoli, 1995.

Kurniawan, Ignasius Yophiandi, “Turun Gunung Membangun Istana. Sembilan Tokoh Agama Menyerukan Gerakan Moral. Dituding Berpolitik Praktis", dalam Tempo (24-30 Januari 2011), hlm. 35

Occhipinti, Giuseppe, (ed.), Storia della Teologia 2: da Pietro Abelardo a Roberto Bellarmino Bologna: Dehoniane, 1996.

Osborne, Kenan B., Priesthood. A History of the Ordained Ministry in the Roman Catholic Church New York/Mahwah: Paulist Press, 1988.

Simamora, Serpulus, "Imam dan Imamat dalam Perspektif Biblis", dalam Persaudaraan 3/VII (Juli-September 2009), hlm. 29-38.

---------, Kitab Nabi-Nabi Besar: Yesaya, Yeremia, Yehezkiel, Daniel (Sinaksak-Pematangsiantar: STFT St. Yohanes, 2004.

Sinaga, Richard R., Communion of Communities: Cara Baru Hidup Menggereja di Asia, Pematangsiantar: Panitia Sinode, 2008.

Viktorahadi, Bhanu, R.F., "The Authenticity of the Word in the Expression 'Yahweh Touching Jeremiah's Mouth' (Jer 1:4-10)", dalam Melintas 25/ 2 (2009), hlm. 179-205.

Vorgrimler, Herbert, (ed.), Commentary on the Documents of Vatican II, Vol. IV, London - New York: Burns and Oates - Herder and Herder, 1967. 